\title{
30
}

\section{Comments on "How should business professionals analyze information systems for themselves?" by S. L. Alter}

\section{P. Kerola}

Dept. of Information Processing Science, University of Oulu P.O. Box 333, FIN-90571 Oulu, Finland

Phone: +358-81-5531902, Fax: +358-81-5531890, E-mail: kerola@rieska,oulu.fi

\section{THE THESIS OF THE PAPER: WORK CENTRED ANALYSIS (WCA) -METHOD}

The hermeneutic and iterative development of the method is well and descriptively presented, but

- the reasoning of focus and constraints is lacking:

- why owners, other stakeholders, financial, raw material and other resources have been left out? (Järvinen and Kerola, 1978)

- why these perspectives (Table 1); where the impacts of the information system into the contextual components?

- the 'boxology' of Fig. 1 is fuzzy:

- in which way 'business process' is a different component of the 'system' compared to three others?

- how the 'system' should be understood in Fig. 1?

\section{QUESTIONS/PROPOSALS FOR FUTURE RESEARCH AND} DEVELOPMENT

- Have you plans to include demographic and/or experiential style data to the evaluative phases of the method (Fig. 4 and Table 4)?

- Have you developed any hypermedia-type of software support for WCA utilization? (cf. QPR-Information, 1995) 


\section{REFERENCES}

Järvinen, P. and Kerola, P. (1978) Notes on research in systemeering. Acta Universitatis Turkuensis, Ser A.I.175, pp. 67-73.

Quality Production and Research (QPR) Information (1995) Cost Control Software a comprehensive $\mathrm{ABC} / \mathrm{M}$ tool to help sharpen your focus.

\section{BIOGRAPHY}

Pentti Kerola is a Professor of Information Processing Science at the University of Oulu. After his studies in applied mathematics at the University of Helsinki, he worked during the 1960s as an operations researcher and manager of ADP development in Finnish industrial enterprises. His main research interests since the early 1970s have included macromodelling of information systems development, human-computer interaction and education of information systems architects. He has been the Finnish national representative on IFIP TC 8 (Information Systems) 1978-94, and as a member of Working Groups 8.1, 8.2 and 8.4. 